\title{
Business Models of the Sharing Economy
}

Cătălin Mihail BARBU ${ }^{1}$

Răducu Stefan BRATU ${ }^{2}$ Elena Mădălina SîRBU ${ }^{3}$

Abstract
Sharing economy is a process of consumption and production in which the
accent goes on shared access to resource, recirculation and reutilization of resources.
As consumers embraced this concept, sharing economy has led to the development of
innovative businesses that compete with traditional businesses.
The aim of the paper is twofold. Firstly, it discusses the business models of the
sharing economy. Based on a research on twelve representative companies of the
sharing economy we analyse three representative business models: access-based,
marketplace, on-demand service provider. Each business model is examined regarding
three dimensions: value creation, value delivery and value capture. Secondly, the
implications for the traditional companies are analysed are emphasized, with an accent
on practical approaches and course of actions. Traditional companies need to
incorporate innovation and technology in their business models in order to gain and
maintain consumer engagement.

Keywords: sharing economy, business models, innovation, value creation.

JEL classification: M10, O33.

DOI: $10.24818 / \mathrm{RMCI} .2018 .2 .154$

\section{Introduction}

Sharing economy is an economic and social system that relies on the concept of shared-use of physical and human resources (Lamberton and Rose, 2012). This system is transposed into a multitude of forms and beneficiates from technology advances to match individuals and organizations, allowing for the sharing and distribution of surplus goods and services. The technical support of the collaborative economy is represented by a platform through which people who need a product/service are connected with other providers of that product/service.

${ }^{1}$ Cătălin Mihail Barbu, University of Craiova, Romania, Faculty of Economics and Business Administration, E-mail: catarom@yahoo.com

${ }^{2}$ Răducu Ştefan Bratu, University of Craiova, Romania, Faculty of Economics and Business Administration, E-mail: braturaducu@yahoo.com

${ }^{3}$ Elena Mădălina Sîrbu, University of Craiova, Romania, Faculty of Economics and Business Administration, E-mail: elenamadalina82@yahoo.com 
Although forms of association for the purchase of high value goods have been observed since ancient times, within groups of people who knew each other very well, the current participative economy has the advantage of bringing in contact people who do not know each other and share the same product. Thus, a service previously provided by an accredited firm is now provided by a person. Contact between people is mediated by technology and a specific platform operated by an entity. The sharing economy thus becomes a method to satisfy the needs of individuals and organizations and it might lead to sustainable use of resources. The activities that take place in the sharing economy are: the production, creation, distribution, trade and consumption of goods and services by organizations and individuals in a common framework (Belk, 2014).

The paper is organized as follows: we provide a literature review of the sharing economy and business models. Then we discuss the most representative business models of the sharing economy and we highlight the implications for the traditional companies.

\section{Literature review}

\subsection{The concept of sharing economy}

The concept of sharing economy is not yet fully clarified in the literature. There are a number of concepts that designate sharing practices: sharing-economy, peer-to-peer economy, collaborative economy, access-based consumption, cocreation, prosumption, etc. Without claiming to make a complete review, we will try to bring a light on these concepts.

The concept and practice of sharing economy and collaborative consumption suggest the use of market information to promote a more collaborative and sustainable society. These systems can be met on a variety of forms and allows individuals, corporations, non-profit organizations and the government to access information in a promptly manner, so that they can share and re-use the overcapacity of goods and services (Heinrichs, 2013).

The digital sharing economy offers individuals opportunities to find temporary jobs, generate additional revenue, increase reciprocity, increase social interaction, and access resources that cannot otherwise be achieved. The sharing economy, also called the peer-to-peer economy and collaboration economy, involves the sharing of physical assets and services between people. Websites and apps such as Uber, Airbnb, and Lyft are platforms that support a sharing economy where individuals can buy and share products or services (Dillahunt and Malone, 2015).

Sharing economy is a phenomenon that generates access to goods and services that are not utilized, and which prioritizes accessibility over of ownership. The sharing economy is based on the use of information technology to provide people with resource optimization information, by shifting the excessive capacity into goods and services (Fang et al., 2016). Sharing economy or collaborative 
economy is the ideal place for reconciling passions and interests (Lougher and Kalmanowicz, 2016).

The morality of the sharing economy is not based on money sharing, but on cooperation and generosity, on common goods and services, on mutual aid and on support for a moral economy involving a very different change from a market economy (Molz, 2013). A number of authors believe that at the base of the sharing economy there is a more responsible attitude of people on consumption practices.

Sheth, et al., (2011) proposed the concept of mindful consumption based on a conscious action on the consequences of consumption. Conscious mindfulness involves concern about the implications and consequences of consumption. In particular, consumers want to avoid wasting and destroying the environment they live in. By engaging in sharing-economy activities, consumers experience a state of well-being by returning something positive to society (Albinsson et al., 2012). Sharing is a key element of collaborative consumption. Belk (2007) define sharing as the act and the process of distributing an item in our property for the benefit of and for use by others. Sharing takes place in multiple contexts, for multiple reasons and multiple results.

Sharing economy involves both collaborative production and collaborative consumption.

Collaborative production require networks of people to design, produce, or distribute goods. Collaborative production activities include collaborative design and collaborative distribution. The economic perspective of the producer involves efforts that are initiated and led by individuals and communities, and not by corporations (Probst et al., 2015). The key elements needed to carry out this activity are sharing economy platforms, which effectively generate sharing markets by facilitating exchanges, but the purpose of generating profits influences the way in which sharing and allocation of revenues takes place. Profitable platforms drive growth in revenue and assets (Schor, 2014). While traditional business people buy, rent or sell products and services, those working in the sharing economy collaborate, facilitate and build relationships based on trust.

Sharing is a pro-social behaviour. Social sharing and sharing are becoming a common way to produce valuable outcomes (Benkler, 2004). A collaborative lifestyle has emerged: people with similar interests combine to share and change less tangible assets such as time, space, skills and money (Botsman and Rogers 2010).

Online collaborative commerce is based on the peer-to-peer interactive platforms operating policy. Collaborative commerce is defined as a form of balanced trade that uses social media to support social interactions and user contributions to engage in purchasing and selling online products and services (Wang and Zhang, 2012).

Collective consumption, often associated with the sharing economy, takes place in organized systems or networks, where the participants carry out sharing activities such as renting, lending, trading, exchanging goods, services, transport solutions, space or money (Möhlmann, 2015).

156 Review of International Comparative Management Volume 19, Issue 2, May 2018 
Collaborative consumption is a system for sharing, hiring, and commercializing goods, reducing personal costs and diminishing environmental impact. In the literature, three forms of collaborative consumption were identified: goods as leased services, pre-existing or worn-out redistribution markets, and collaborative life-styles (Botsman and Rogers, 2010).

\subsection{Business models}

The emergence of the business model concept is relatively recent in nature, being related to the diversification of traditional resources and processes used by organizations to provide value propositions for consumers in profitable conditions. Often, the business model is synonymous with an alternative to a traditional business. Many new information and communication technologies are often embedded or used in a business model.

The business model is the way an organization chooses to generate revenue and how it creates value for customers (Timmers, 1998). The business model is important because it ensure the identity of an organization. The business model should not be confused with the business strategy or the marketing strategy. In their study, Zott et al. (2011) examine the literature on business models by analysing over 100 relevant papers. They show that the business model can be conceptualized as the way to conduct the businesses of a company, focusing on the description of the activity and the structure of costs and revenues. The business model used by a company may represent the source of competitive advantage (Markides and Charitou, 2004). Based on the business model, a strategy can be formulated to guide the activity of an organization (Richardson, 2008).

The business model is a concept that has the ability to mobilize the technical potential to transform it into a profitable economic business. The business model mediates the relationship between technology and economic value (Chesbrough and Rosenbloom, 2002). The business model is a framework to make money. It is the set of activities that a firm carries out, how it performs its tasks, so as to give customers the benefits they want and implicitly to obtain a profit (Afuah, 2004, pp.415).

The business model is a useful framework for linking ideas and technologies to economic outcomes (Chesbrough, 2006). A business model is the tool by which a business plans to generate revenue and profits. It is a summary of how a company attempts to serve its clients and involves both strategy and implementation (Debelak, 2006). The business model is a profit formula, a business system and learning system. The business model is a mechanism for transforming ideas into income through acceptable costs (Baden-Fuller and Morgan, 2010).

A business model describes the company's operations, including all its components, functions and processes, which determine the costs for itself and the value for the client (Watson, 2005). The business model defines how a company delivers value to customers and transforms payments to profit (Teece, 2010). The 
business model is the way through which a company can generate revenue. The business model specifies how a company earns money by detailing its position in the value chain (Rappa, 2010).

The business model is an example of a scheme, defined as a cognitive structure that consists of concepts and relationships, organizing managerial understandings about project design and exchanges that reflect critical interdependencies and value creation relationships in organizations' exchange networks (Martins et al., 2015). A business networking model guides how a network of firms will create value for customers and the network by developing collective understanding of business opportunities and modelling their actions (Palo and Tähtinen, 2013).

A business model is a conceptual tool that contains a set of elements and relationships between them, allowing the expression of an organization's business logic. It is a description of the value a company offers for one or more customer segments, the company architecture, and its partner networks for creating, marketing and delivering this value and relationship capital, in order to generate streams of profitable and sustainable incomes (Osterwalder et al., 2005).

In the literature, a number of authors have attempted to detail the structure of a business model, its essential elements (table 1). Chesbrough and Rosenbloom (2002) consider that a business model should include: value proposition, market segment, value network, value chain, revenue generation, cost structure and profit potential. Kaplan (2012) appreciates that a business model should not omit: value creation, value delivery and value capture. Johnson et al. (2008) include in a business model: customer value proposition, key resources, key processes and profit formula. According to Osterwalder and Pigneur (2010) a business model includes the following: value proposition, customer segments, customer relationships, key partners, key resources, channels, key activities, cost structure and revenue streams. For Morris et al. (2005) a business model has six components: value proposition, customer, internal processes, external positioning, economic model and personal factors.

Table 1. Structure of business model

\begin{tabular}{|c|l|l|l|l|l|}
\hline $\begin{array}{l}\text { Key } \\
\text { elements }\end{array}$ & $\begin{array}{c}\text { Chesbrough } \\
\text { and } \\
\text { Rosenbloom } \\
\mathbf{( 2 0 0 2 )}\end{array}$ & $\begin{array}{l}\text { Morris et } \\
\text { al. (2005) }\end{array}$ & $\begin{array}{l}\text { Johnson et } \\
\text { al. (2008) }\end{array}$ & $\begin{array}{l}\text { Osterwalder } \\
\text { and Pigneur } \\
\mathbf{( 2 0 1 0 )}\end{array}$ & $\begin{array}{c}\text { Kaplan } \\
\mathbf{( 2 0 1 2}\end{array}$ \\
\hline Value proposition & $\begin{array}{l}\text { Value } \\
\text { proposition }\end{array}$ & $\begin{array}{l}\text { Customer } \\
\text { value } \\
\text { proposition }\end{array}$ & $\begin{array}{l}\text { Value } \\
\text { proposition }\end{array}$ & $\begin{array}{l}\text { Value } \\
\text { creation }\end{array}$ \\
\hline Market segment & Customers & $\begin{array}{l}\text { Key } \\
\text { resources }\end{array}$ & $\begin{array}{l}\text { Customer } \\
\text { segments }\end{array}$ & $\begin{array}{l}\text { Value } \\
\text { delivery }\end{array}$ \\
\hline Value network & $\begin{array}{l}\text { Internal } \\
\text { processes }\end{array}$ & $\begin{array}{l}\text { Key } \\
\text { processes }\end{array}$ & $\begin{array}{l}\text { Customer } \\
\text { relationships }\end{array}$ & $\begin{array}{l}\text { Value } \\
\text { capture }\end{array}$ \\
\hline Value chain & External & Profit & Key partners & \\
\hline
\end{tabular}

158 Review of International Comparative Management Volume 19, Issue 2, May 2018 


\begin{tabular}{|c|c|c|c|c|c|}
\hline $\begin{array}{l}\text { Authors } \\
\text { Key } \\
\text { elements }\end{array}$ & $\begin{array}{l}\text { Chesbrough } \\
\text { and } \\
\text { Rosenbloom } \\
(\mathbf{2 0 0 2}) \\
\end{array}$ & $\begin{array}{l}\text { Morris et } \\
\text { al. (2005) }\end{array}$ & $\begin{array}{l}\text { Johnson et } \\
\text { al. (2008) }\end{array}$ & $\begin{array}{l}\text { Osterwalder } \\
\text { and Pigneur } \\
\text { (2010) }\end{array}$ & $\begin{array}{c}\text { Kaplan } \\
\text { (2012) }\end{array}$ \\
\hline \multirow{2}{*}{\multicolumn{2}{|c|}{ Revenue generation }} & positioning & formula & & \\
\hline & & $\begin{array}{l}\text { Economic } \\
\text { model }\end{array}$ & & Key resources & \\
\hline \multicolumn{2}{|r|}{ Cost structure } & $\begin{array}{l}\text { Personal } \\
\text { factors }\end{array}$ & & Channels & \\
\hline \multirow{3}{*}{\multicolumn{2}{|c|}{ Profit potential }} & & & Key activities & \\
\hline & & & & Cost structure & \\
\hline & & & & $\begin{array}{l}\text { Revenue } \\
\text { streams }\end{array}$ & \\
\hline
\end{tabular}

For the purpose of our paper we will use the structure of a business model emphasized by Kaplan (2012).

\section{Business models of the sharing economy}

To describe the business models proposed by the sharing economy, we analysed a total of 12 representative company for the sharing economy. The documentary research involved consulting companies' sites, media and scientific articles. The list of companies investigated is presented in Appendix 1. We cannot say that the companies analysed fit into the characteristics of just a single business model. There are many points of overlap between the business models developed by these companies. The main business models of the sharing economy, documented in the literature are (Demary, 2015):

- Access-based business model;

- Marketplace/platform economy;

- On-demand service provider.

\section{The access-based business model}

This models is based on underutilized resources, for this reason being also known as the "surplus capacity" business model. The access business model is consolidated on the principle of access to various goods and services through an online platform. The consumer, instead of buying the product, will access it when he needs it (Bardhi and Eckhardt, 2012). The platform holder provides tangible and intangible assets that can be leased by interested users. The products are provided by the owner of the platform or by other partner organizations. An example in this regard is the Luxembourg company FLOOW2 or the car rental service Getpony in Romania.

The implications of the Access-based model are important as it leads to a reorientation of customers towards a new way of thinking and behaviour, in which access to the product is more important than the product ownership. This translates from ownership to usage. Value creation within this model is achieved through the 
economy that consumers receive due to the fact that they no longer become owners. Delivery value is made through the platform and the locations where the requested product can be accessed. Value capture is done by charging users, service beneficiary a fee, most often for the time they use the product. Traditional companies realized the potential of this business-model and they developed what is recognized under the name of "product as a service" business model.

\section{The marketplace business model}

The channel or platform is the basics that are part of the business marketplace model, where customer relationships are in most cases automated. The operator of the marketplace platform succeeds in facilitating access to transactions. An example of this is Airbnb connecting homeowners with those who want to stay or BlaBlaCar, a company that facilitates the transport of people between localities.

Depending on the stakeholders and the specificity and nature of the business, the key activities of the marketplace organizations can be varied. The marketplace model offers advantages to all involved parties, gaining an important significance, since without these services the value cannot be passed to the target group.

The marketplace value creation model is achieved by ensuring faster and safer market access for participants. Essentially, the marketplace connects demand and supply. Delivery value is met through the on-line platform. Value capture is obtained by charging the parties involved in the exchange, rental or purchase of goods or services. The Marketplace business model broadens the market for traditional products and services. By supplying the market with existing overcapacity to individuals, this model generates competition for the traditional sectors such as transport, accommodation, etc.

\section{On-demand service provider}

Within the on-demand service provider business model, customer-focused service activities are deployed. The users require specific services to be provided by other persons or by specialized companies. The exchange is beneficial for both parties.

Channels are the basic tools of the on-demand service provider business model. This pattern is different depending on the distribution campaign. Due to the contact between the service provider and the service requester, within this business model the relationships that are established and developing get a higher level of confidence. Within this model there are two categories of participants: service providers and those in need of such services. Value creation is achieved by quickly matching the two categories. Value delivery is made through the application. Value capture is done by charging service users.

The match of service providers and service users within the sharing economy is done through a software platform and Internet access. The platform has the role of ensuring the efficiency of the transactions, but at the same time it offers

160 Review of International Comparative Management

Volume 19, Issue 2, May 2018 
the opportunity to evaluate both the provider and consumers through a rating system.

\section{Implications for traditional businesses}

The success of business of the sharing economy can be explained by the fact that the business model proposed by them is able to create, deliver and capture value.

The business models of the sharing economy discussed in this paper have great potential for development and enhancement in the future. The results of our study are also consistent with the results of other authors who have shown that sharing economy business models are compatible with sustainable development (Daunorienė et al., 2015). Traditional companies have to question whether their business models are not affected by sharing economy (Kathan et al., 2016). In addition, many traditional companies have adapted their offer to meet changes in consumer behaviour. For example, there are car companies offering cars based on access, by providing the car as a rental service and not as a property transfer (eg The DriveNow service by BMW). We appreciate that traditional businesses need to focus on five elements to take advantage of the sharing economy models: continuous learning, adaptability and flexibility, digitalization, consumer experience and innovation.

Continuous learning is essential to enable businesses to generate an appropriate value proposition. Continuous learning is based on the continuous scanning of the environment to keep up to date with the latest developments in the field (Nistorescu and Barbu, 2008). Human resources are important in the process of continuous learning, and businesses need to provide both soft skills and hard skills training. Knowledge management and the integration of this knowledge is also very important. Organizations must establish channels to acquire and implement knowledge (Crăciun and Scrioşteanu, 2008).

Adaptability and flexibility refers to the pace with which the enterprise implements change. Modern organizations must be able to operate different business models according to market requirements. Flexibility also takes into account the elasticity of organizational structures. Symon (2000) described the appearance of post-bureaucratic forms of organization that are more elastic, more flexible and responsive to change.

Digitalization is a condition of keeping in touch with customers, as consumers spend a good amount of time connected to the Internet. Digitalization should be present in all process of an organization: value creation, value delivery and value capture. Digitalization must ultimately offer a personalized offer and a more personal consumer experience.

Consumer experience will take into account that consumers want to be surprised with attractive offers. Organizations need to find solutions to reinvent the consumption of certain products or services. Consumer experience is related to the establishment of rational and emotional links between the firm and the consumer 
(Keller, 2008). Consumer experience should not be neglected at any time when the consumer comes into contact with the organization.

Innovation is a requirement for businesses to be able to keep consumers' attention. Innovation is closely related to managing consumer experience and enhancing brand responses (Florea, 2015). In knowledge-based society, information is power and organizations must be able to direct knowledge management towards innovative products and services (Năstase and Hotăran, 2011). Innovation can mean both new products and services, but also reconfiguration of business models so as to extend customer base in the most profitable conditions. Innovation of business models must keep pace with adapting to new trends so that value can be created and delivered using new technologies.

\section{Conclusions}

As an ongoing process, the sharing economy competes with traditional economic activities and creates pressure for the traditional companies. For the consumer, the sharing economy widens the range of available choices. Traditional businesses are adapting to this trend and offering access-based services instead of property-based.

Sharing economy enhances competition in traditional markets and democratizes access to services and products. The success of the sharing economy initiatives demonstrates the viability of their business models. Since many of the sharing economy initiatives are associated with innovation (Martin, 2016; Schor 2014), these models deserve the attention of specialists in the field. Although the business models are not entirely new, the ability of sharing economy firms to implement these models has led to their success and recognition.

A business model describes the logic of how an organization creates, offers and controls the value and the way money is earned in a company (Osterwalder and Pigneur, 2009). A business model is a system of activities that describes how a company is doing business with its customers, partners, and suppliers. Specifically, a business model is a package of specific activities that are tailored to meet the perceived needs of the market, including the specification of the parties conducting these activities and how these activities are linked (Amit and Zott, 2010). We have shown that business models are important because they have the ability to integrate various resources of the organization. In particular, for the purpose of the sharing economy, the interest for business models is how new technologies combine with traditional processes or manage to generate commercial applications for new technologies (Calia et al., 2007; Zott et al., 2011).

The main contributions of our paper refer to the description of the sharing economy models and the analysis of their success formula. We emphasize the need for traditional firms to take into account new business models and to try to incorporate them into their current work. The main limitations of the paper are that the sample of companies analysed is relatively small and the fact that we have only taken into account certain elements of the business plan. Future possible directions

162 Review of International Comparative Management Volume 19, Issue 2, May 2018 
for research can be channelled into analysing how business models that are successful for the sharing economy can be applied by a wider range of organizations, including small and medium sized enterprises or employed to develop businesses abroad. Also, the analysis of the business models of the sharing economy might be realized in-depth by taken into account a more detailed structure of the business models.

\section{References}

1. Afuah, A., 2004. Business Models: A Strategic Management Approach. New York: McGraw-Hill/Irwin.

2. Albinsson, P. A., Yasanthi Perera, B., 2012. Alternative marketplaces in the 21st century: Building community through sharing events. Journal of Consumer Behaviour, 11(4), pp. 303-315.

3. Amit, R., Zott, C. 2010. Business model innovation: creating value in times of change. IESE Business School, University of Navara. Available online at: https://www.iese.edu/research/pdfs/di-0870-e.pdf, accessed 22 March 2018.

4. Baden-Fuller, C.H., Morgan, M.S., 2010. Business Models as Models. Long Range Planning, 43(2), pp. 156-171.

5. Bardhi, F., Eckhardt, M., 2012. Access-Based Consumption: The Case of Car Sharing. Journal of Consumer Research, 39(4), pp. 881-898.

6. Belk, R., 2007. Why not share rather than own? The Annals of the American Academy of Political and Social Science, 611, pp. 126-140.

7. Belk, R., 2014. You are what you can access: Sharing and collaborative consumption online. Journal of Business Research, 67(8), pp.1596-1600.

8. Benkler, Y. 2004. Sharing Nicely: On Shareable Goods and the Emergence of Sharing as a Modality of Economic Production. The Yale Law Journal, 114(2), pp. 273-358.

9. Botsman, R., Rogers, R., 2010. What's mine is yours - the rise of collaborative consumption. New York: HarperCollins.

10. Calia, R.C., Guerrini, F.M., \& Moura, G.L., 2007. Innovation networks: From technological development to business model reconfiguration. Technovation, 27, pp. 426-432.

11. Chesbrough, H., 2006. Open Business Models: How to Thrive in the New Innovation Landscape. Business School Press. Boston: Harvard.

12. Chesbrough, H., Rosenbloom, R.S., 2002. The role of the business model in capturing value from innovation: Evidence from Xerox Corporation's technology spin-off firms. Industrial and Corporate Change, 11(3), pp. 529555 .

13. Cohen, B., Kietzmann, J., 2014. Ride On! Mobility Business Models for the Sharing Economy. Organization \& Environment, 27(3), pp. 279-296. 
14. Crăciun, L., Scrioşteanu, A., 2008. How to measure intellectual capital, Annals of the University of Craiova. Economic Sciences Series 3 (36), pp. 1239-1244.

15. Daunorienè, A., Drakšaite, A., Snieška V., Valodkienè G. 2015. Evaluating Sustainability of Sharing Economy Business Models. Procedia - Social and Behavioral Sciences, 213, pp. 836-841.

16. Debelak, D., 2006. Business model made easy. Wisconsin: CWL Publishing Enterprises.

17. Demary, V., 2015. Competition in the Sharing Economy. Available online at: https://www.iwkoeln.de/fileadmin/publikationen/2015/235445/Sharing

_Economy_Policy_Paper.pdf, accessed 18 March 2018.

18. Dillahunt, T., Malone, A., 2015. The Promise of the Sharing Economy among Disadvantaged Communities. Paper presented at the Proceedings of the 33rd Annual ACM Conference on Human Factors in Computing Systems, Seoul, Republic of Korea.

19. Fang, B., Ye, Q., Law, R., 2016. Effect of sharing economy on tourism industry employment. Annals of Tourism Research. vol. 57, issue C, pp. 264267.

20. Florea, D., 2015. The Relationship Between Branding and Diffusion of Innovation. A Systematic Review, Procedia Economics and Finance, 23, pp. 1527-1534.

21. Heinrichs, H., 2013. Sharing economy: A potential new pathway to sustainability. GAIA, 22(4), pp. 228-231.

22. Johnson, M. W., Christensen, C. M., Kagermann, H., 2008. Reinventing your business model. Harvard Business Review, 86(12), pp. 50-60.

23. Kaplan, S., 2012. The Business Model Innovation Factory: How to Stay Relevant When The World is Changing. Hoboken, NJ: Wiley.

24. Kathan W. Matzler, K., Veider, V., 2016, The sharing economy: Your business model's friend or foe? Business Horizons, 59(6), pp. 663-672.

25. Keller K., 2008. Strategic brand management. Prentice Hall.

26. Lamberton, C.P., Rose, R.L., 2012. When is ours better than mine? A framework for understanding and altering participation in commercial sharing systems. Journal of Marketing, 4(76), pp. 109-125.

27. Lougher, G., Kalmanowicz, S., 2016. EU Competition Law in the Sharing Economy. Journal of European Competition Law \& Practice, 7(2), pp. 87102.

28. Markides, C., Charitou, C.D., 2004. Competing with dual business models: A contingency approach. Academy of Management Executive, 18, pp. 22-36.

29. Martin C., 2016. The sharing economy: A pathway to sustainability or a nightmarish form of neoliberal capitalism? Ecological Economics, 121, pp.149-159.

30. Martins, L.L., Rindova, V.P., Greenbaum, B.E., 2015. Unlocking the hidden value of concepts: A cognitive approach to business model innovation. Strategic Entrepreneurship Journal, 9(1), pp. 99-117. 
31. Möhlmann, M., 2015. Collaborative consumption: determinants of satisfaction and the likelihood of using a sharing economy option again. Journal of Consumer Behaviour, 14(3), pp. 193-207.

32. Molz, J.G., 2013. Social networking technologies and the moral economy of alternative tourism: The case of couchsurfing.org. Annals of tourism research, 43, pp. 210-230.

33. Morris, M., Schindehutte, M., Allen, J., 2005. The entrepreneur's business model: Toward a unified perspective. Journal of Business Research, 58(6), pp. 726-35.

34. Năstase, M., Hotăran, I., 2011. Fostering the Organizational Leadership within the Knowledge Based Economy. Review of International Comparative Management, 4(12), pp. 661-672.

35. Nistorescu, T., Barbu, C.M., 2006. A model for enterprises' environmental scanning. Management \& Marketing, 4(1), pp. 57-62.

36. Osterwalder, A., Pigneur, Y., 2010. Business Model Generation: A Handbook for Visionaries, Game Changers, and Challengers. Hoboken: Wiley.

37. Osterwalder, A. Pigneur, Y., Tucci, C.L., 2005. Clarifying business models: Origins, present and future of the concept. Communications of the Association for Information Systems, 16, pp. 1-40.

38. Palo, T., Tähtinen, J., 2013. Networked business model development for emerging technology-based services. Industrial Marketing Management, 42, pp. 773-782.

39. Probst, L., Frideres, L., Pedersen, B., \& Lidé, S. 2015. Collaborative Economy. Collaborative production and the maker economy. Brussels: European Commission, Directorate-General Growth.

40. Rappa, M., 2010. Business Models on the Web. Available online at: http://digitalenterprise.org/models/models.html, accessed on 20 March 2018.

41. Richardson, J., 2008. The business model: An integrative framework for strategy execution. Strategic Change, 17 (5/6), pp. 133-144.

42. Schor, J., 2014. Debating the Sharing Economy. Great Transformation Initiative. Available online at: http://greattransition.org/publication/ debating-the-sharingeconomy, accessed on 15 March 2018.

43. Sheth J.N. Sethia, N.K. \& Srinivas, S., 2011. Mindful consumption: A customer-centric approach to sustainability. Journal of the Academy of Marketing Science, 39(1), pp. 21-39.

44. Symon, G. 2000. Information and communication technologies and the network organization: A critical analysis. Journal of Occupational and Organizational Psychology, 4(73), pp. 389-414.

45. Teece, J.D., 2010. Business Models, Business Strategy and Innovation. Long Range Planning, 43(2), pp. 172-194.

46. Timmers, P., 1998. Business models for electronic markets. Electronic Markets, 8(2), pp. 3-8. 
47. Wang, C., \& Zhang, P., 2012. The evolution of social commerce: The people, management, technology, and information dimensions. Communications of the Association for Information Systems, 31(1), pp. 105-127.

48. Watson, D., 2005. Business Models. Petersfield: Harriman House Ltd.

49. Zott, C. Amit, R., \& Massa, L., 2011. The business model: recent developments and future research. Journal of Management, 37(4), pp. 10191042 .

\section{Appendix 1. List of analysed companies}

\begin{tabular}{|l|l|l|}
\hline \multicolumn{1}{|c|}{ Company } & \multicolumn{1}{c|}{ Sector } & \multicolumn{1}{c|}{$\begin{array}{c}\text { Predominant Business } \\
\text { model }\end{array}$} \\
\hline Uber & Transportation & Marketplace \\
\hline Airbnb & Accommodation & Marketplace \\
\hline BlaBlaCar & Transportation & Marketplace \\
\hline Lyft & Transportation & Marketplace \\
\hline Kickstarter & Financial services & Marketplace \\
\hline Taskrabbit & Services & On-demand service provider \\
\hline Getpony & Transportation & Access-based \\
\hline Getaround & Transportation & Access-based \\
\hline Mutum & Services & Access-based \\
\hline Zaarly & Services & On-demand service provider \\
\hline Poshmark & Fashion & Marketplace \\
\hline Lending Club & Financial services & Marketplace \\
\hline
\end{tabular}

